\title{
COMPARATIVE STUDY OF EPIDURAL FENTANYL AND FENTANYL PLUS MAGNESIUM FOR POSTOPERATIVE ANALGESIA
}

\author{
Rashmi N. R1, Shashidhar G. S2, Sumitha C. S3, B. Devanand 4
}

${ }^{1}$ Assistant Professor, Department of Anaesthesiology and Pain Relief, Kidwai Memorial Institute of Oncology, Bengaluru. ${ }^{2}$ Assistant Professor, Department of Anaesthesiology and Pain Relief, Kidwai Memorial Institute of Oncology, Bengaluru. ${ }^{3}$ Assistant Professor, Department of Anaesthesiology and Pain Relief, Kidwai Memorial Institute of Oncology, Bengaluru. ${ }^{4}$ Professor and HOD, Department of Anaesthesiology and Pain Relief, Vijayanagar Institute of Medical Sciences, Bellary.

\section{ABSTRACT}

\section{BACKGROUND AND OBJECTIVES}

Magnesium has antinociceptive effects in animal and human models of pain. It is found that the addition of magnesium to postoperative epidural infusion of fentanyl may decrease the need for fentanyl. We undertook a study to compare the duration of postoperative analgesia after epidural Fentanyl and epidural Fentanyl plus magnesium administered postoperatively, along with side effects.

\section{METHODS AND MATERIALS}

50 patients undergoing elective lower limb surgeries were randomized into one of the two groups with 25 patients in each group. Combined Spinal Epidural Anaesthesia was used for all patients. Spinal anaesthesia with $2.5 \mathrm{cc}$ of $0.5 \%$ hyperbaric bupivacaine was given. When sensory blockade regressed to L1, patients were given either $50 \mu \mathrm{g}$ of Fentanyl (Diluted to $6 \mathrm{cc}$ with normal saline, Group F) or $50 \mu \mathrm{g}$ of Fentanyl plus $50 \mathrm{mg}$ Magnesium (Diluted to $6 \mathrm{cc}$ with normal saline, Group FM). Study drugs are administered by epidural route. Parameters like blood pressure, pulse rate, respiratory rate and oxygen saturation were monitored, and other side effects were noted

\section{STATISTICAL ANALYSIS}

Data were analysed by using Student $t$ test and Chi-square/ Fisher Exact tests.

\section{RESULTS}

There was significant difference in duration of analgesia between Group F (107 min) and Group FM (143 min). Haemodynamic parameters were stable in both the groups with minimal side effects.

\section{CONCLUSION}

Co-administration of magnesium along with fentanyl for postoperative epidural analgesia results in prolongation of fentanyl analgesia without significant side-effects.

\section{KEYWORDS}

Epidural Magnesium, Epidural Fentanyl, Postoperative Analgesia, NMDA Receptor.

HOW TO CITE THIS ARTICLE: Rashmi NR, Shashidhar GS, Sumitha CS, et al. Comparative study of epidural fentanyl and fentanyl plus magnesium for postoperative analgesia. J. Evolution Med. Dent. Sci. 2016;5(36):2154-2158, D0I: 10.14260/jemds/2016/502

\section{INTRODUCTION}

Acute pain has been defined as "the normal, predicted, physiological response to an adverse chemical, thermal, or mechanical stimulus. ${ }^{1 "}$ Poorly managed acute pain that might occur following surgery can produce pathophysiologic processes in both the peripheral and central nervous systems that have the potential to produce chronicity. ${ }^{2}$ Acute paininduced change in the central nervous system is known as neuronal plasticity. This can result in sensitisation of the nervous system resulting in allodynia and hyperalgesia. ${ }^{3}$ Postoperative pain being acute pain has to be addressed during perioperative period. Continuous spinal epidural (CSE) block combines the rapidity, density, and reliability of the subarachnoid block with the flexibility of continuous epidural block to extend duration of analgesia.

Financial or Other, Competing Interest: None.

Submission 19-03-2016, Peer Review 14-04-2016,

Acceptance 20-04-2016, Published 05-05-2016.

Corresponding Author:

Dr. Rashmi N. R,

Assistant Professor,

Department of Anaesthesiology and Pain Relief,

Kidwai Memorial Institute of Oncology,

Bengaluru.

E-mail: drrashmisatheesh@gmail.com

DOI: 10.14260/jemds/2016/502
The CSE technique is used routinely for major orthopaedic surgery and in obstetrics. ${ }^{4}$ The role of epidural anaesthesia and analgesia in reducing the incidence and severity of perioperative physiologic derangements, in addition to relieving pain has been reported in several studies.5,6 Epidural opioids are proven to be very effective for postoperative analgesia. The rapidity of analgesic effect of epidural fentanyl administration and the relatively short duration of action makes it the drug of choice for acute postoperative pain.7 Magnesium, the non-competitive $\mathrm{N}$ Methyl D-Aspartate (NMDA) antagonist, administered intrathecally, is proved to prolong the duration of spinal opioid analgesia in humans. ${ }^{8}$

Co-administration of epidural magnesium for postoperative analgesia has provided a pronounced reduction in patient-controlled epidural fentanyl consumption without any side effects. ${ }^{9}$ On the basis of these evidences, a study was undertaken to compare the effects of epidural fentanyl and fentanyl plus magnesium on duration of analgesia, haemodynamic stability and side effects in patients undergoing elective lower limb orthopaedic surgeries.

\section{MATERIAL AND METHODS}

The present study was a prospective, randomised, comparative clinical study, conducted in patients scheduled to 
undergo elective lower-limb surgeries in Medical College Hospital (MCH), Vijayanagar Institute of Medical Sciences (VIMS), Bellary, Karnataka. Ethical clearance was obtained from VIMS Institutional Ethics committee. 50 patients scheduled to undergo elective lower limb orthopaedic surgeries were selected for the study and randomly allocated into one of the two groups. Group F (25 patients) to receive epidural fentanyl $50 \mu \mathrm{g}(1 \mathrm{~mL})$ diluted and made up to $6 \mathrm{cc}$ with normal saline. Group FM (25 patients) to receive epidural fentanyl $50 \mu \mathrm{g}(1 \mathrm{~mL})+$ magnesium sulphate (MgSO4) $50 \mathrm{mg}$ ( $50 \%$ solution- 4 units in insulin syringe) diluted and made up to $6 \mathrm{cc}$ with normal saline.

Preoperatively, routine investigations like Haemoglobin\%, Blood Grouping \& Rh typing, Bleeding time, clotting time, RBS, Blood Urea Nitrogen, Serum Creatinine, Urine routine were done, and ECG, X-ray chest, Serum Electrolytes if necessary. Informed/written consent was obtained from each patient before starting the study. Patients aged between 35 and 45 years of age posted for elective lower limb surgeries and ASA grade I/II were included in the study. Patients who refused CSE block, morbidly obese patients, patients with vertebral column defects or significant neurological deficits were excluded from the study. A specially designed Proforma was used to collect the data including patient's particulars, indication for surgery, the anaesthetic details, intra-operative monitoring, postoperative follow-up, etc.

\section{Anaesthetic Procedure: Combined Spinal Epidural Technique}

After securing IV access, infusion of Ringer Lactate $10 \mathrm{~mL} / \mathrm{kg}$ was started. Pulse-oximeter, Non Invasive Blood Pressure (NIBP) monitor and Electrocardiogram (ECG) were connected. Basal parameters like pulse rate (PR), oxygen saturation $\left(\mathrm{SPO}_{2}\right)$, NIBP and respiratory rate (RR) were recorded. Patient was put in lateral or sitting position. Under strict aseptic precautions, the back was painted and draped. The skin was infiltrated with about $2 \mathrm{~mL}$ of $1 \%$ lignocaine at L2-L3 or L3- L4 intervertebral space. The epidural space was identified by midline approach using 16 gauge Tuohy's needle by loss of resistance technique. Dural puncture was performed by a needle-through-needle technique with a 26G spinal needle and $2.5 \mathrm{~mL}$ of $0.5 \%$ Bupivacaine heavy injected into the intrathecal space. $16 \mathrm{G}$ epidural catheter was then inserted into the epidural space and secured. Routine intra-operative monitoring of PR, SPO2, NIBP and RR was done for all the patients and the following parameters were noted.

1. Time taken for Highest Sensory Block

It is time taken from giving spinal anaesthesia to maximum height for loss of pinprick sensation (checked by pin prick with $23 \mathrm{G}$ hypodermic needle).

2. Time for Regression to $\mathbf{L 1}$

It is time taken for the sensory blockade to regress to L1 after reaching highest sensory level.

3. Duration of Surgery

It is time taken from skin incision to completion of surgery.

4. Duration of Analgesia

It is the time interval from administration of study drug to the first complaint of pain by the patient.
After regression of sensory block to L1, patients in Group F received $50 \mu \mathrm{g}$ of fentanyl and Group FM received $50 \mu \mathrm{g}$ of fentanyl plus $50 \mathrm{mg} \mathrm{MgSO}_{4}$. Study drugs are given through epidural catheter. Patients were monitored for duration of analgesia (as described above), $\mathrm{PR}, \mathrm{SPO}_{2}, \mathrm{NIBP}, \mathrm{RR}$ and side effects like nausea, vomiting, pruritus, shivering, etc. After 30 minutes of monitoring in PACU, patients were transferred to postoperative ward. Patients' first analgesic requirement time were recorded. Adverse events related to drug and epidural catheter were observed for 24 hrs. Results obtained were recorded, compared and analysed statistically.

\section{Statistical Methods:.10,11}

Descriptive statistical analysis was carried out. Results obtained on continuous measurements are presented on Mean \pm SD (Min-Max) and results on categorical measurements are presented in Number (\%). Significance is assessed at $5 \%$ level of significance. Student t test (two tailed, independent) is used to find the significance of study parameters on continuous scale between two groups. Chi-square/Fisher Exact test are used to find the significance of study parameters on categorical scale between two or more groups.

\section{Significant figures are Denoted as}

+ Suggestive significance ( $\mathrm{P}$ value: $0.05<\mathrm{P}<0.10$ ).

* Moderately significant (P value: $0.01<\mathrm{P} \leq 0.05$ ).

** Strongly significant ( $\mathrm{P}$ value: $\mathrm{P} \leq 0.01$ ).

The Statistical software namely SPSS 15.0, Stata 8.0, MedCalc 9.0.1 and Systat 11.0 were used for the analysis of the data and Microsoft Word and Excel have been used to generate graphs, tables etc.

\section{RESULTS}

A comparative study of 50 patients randomly divided into two groups with 25 patients in Group F (Epidural Fentanyl) and 25 patients in Group FM (Fentanyl + Magnesium) was undertaken to study the efficacy of the drugs in relation to duration of analgesia, and haemodynamic stability and incidence of adverse effects.

\section{Age and Gender Distribution}

\begin{tabular}{|c|c|c|c|}
\hline $\begin{array}{c}\text { Age and } \\
\text { Gender }\end{array}$ & $\begin{array}{c}\text { Group } \\
\text { F }\end{array}$ & $\begin{array}{c}\text { Group } \\
\text { FM }\end{array}$ & Significance \\
\hline Age in years & $39.92 \pm 4.23$ & $40.6 \pm 4.46$ & $\mathrm{t}=0.553 ; \mathrm{p}=0.583$ \\
\cline { 1 - 3 } Male & $18(72.0 \%)$ & $\begin{array}{c}18 \\
(72.0 \%)\end{array}$ & \multirow{2}{*}{$\chi^{2}=0.000 ; \mathrm{P}=1.000$} \\
\cline { 1 - 3 } Female & $7(28.0 \%)$ & $7(28.0 \%)$ & \\
\cline { 1 - 3 } Table 1: Age and Gender Distribution of Patients Studied \\
\hline
\end{tabular}

The age and gender distribution in Group F and FM were comparable with $\mathrm{p}=0.583$ and $\mathrm{p}=1$ respectively.

\section{Highest Sensory Block Attained}

\begin{tabular}{|c|c|c|}
\hline $\begin{array}{c}\text { Highest Sensory } \\
\text { Blockade }\end{array}$ & $\begin{array}{c}\text { Group F } \\
\text { (n=25) }\end{array}$ & $\begin{array}{c}\text { Group FM } \\
\text { (n=25) }\end{array}$ \\
\hline T10 & 0 & $3(12.0 \%)$ \\
\hline T8 & $7(28.0 \%)$ & $6(24.0 \%)$ \\
\hline T6 & $15(60.0 \%)$ & $15(60.0 \%)$ \\
\hline T5 & $3(12.0 \%)$ & $1(4.0 \%)$ \\
\hline Inference & $\begin{array}{c}\text { Highest sensory blockade is statistically } \\
\text { similar between two groups with } \mathrm{P}=0.324\end{array}$ \\
\hline \multicolumn{2}{|c|}{ Table 2: Comparison of Highest Sensory Level } \\
\hline
\end{tabular}

Highest sensory level (T6) achieved in maximum number of patients $(60 \%)$ is same in both groups. 
Time taken for Attainment of Highest Sensory Level and Duration of Surgery

\begin{tabular}{|c|c|c|c|}
\hline Variables & Group F & Group FM & Significance \\
\hline $\begin{array}{c}\text { Time taken } \\
\text { for highest } \\
\text { sensory level } \\
\text { (min.) }\end{array}$ & $13.92 \pm 4.50$ & $12.24 \pm 3.43$ & $\mathrm{~T}=1.485 ; \mathrm{p}=0.144$ \\
\hline $\begin{array}{c}\text { Duration of } \\
\text { surgery } \\
\text { (min.) }\end{array}$ & $99.00 \pm 13.31$ & $92.20 \pm 15.21$ & $\mathrm{~T}=1.682 ; \mathrm{p}=0.099$ \\
\hline \multicolumn{3}{|c|}{ Table 3: Comparison of time taken for } \\
Highest Sensory Level \& Duration of Analgesia \\
\hline
\end{tabular}

Time taken for highest sensory level and duration of surgery in both the groups were comparable.

Time for Regression of Sensory Block to L1 and Duration of Analgesia

\begin{tabular}{|c|c|c|c|}
\hline Variables & Group F & Group FM & Significance \\
\hline $\begin{array}{c}\text { Time for } \\
\text { Regression } \\
\text { to L1 } \\
\text { (min) }\end{array}$ & $118.80 \pm 13.41$ & $119.60 \pm 17.85$ & $\mathrm{~T}=0.179 ; \mathrm{p}=0.859$ \\
\hline $\begin{array}{c}\text { Duration } \\
\text { of } \\
\text { analgesia } \\
\text { (min) }\end{array}$ & $107.00 \pm 25.82$ & $143.40 \pm 39.57$ & $\mathrm{~T}=3.852 ; \mathrm{p}<0.001^{* *}$ \\
\hline \multicolumn{3}{|c|}{ Table 4: Comparison of time for Regression } \\
to L1 and Duration of Analgesia \\
\hline \multicolumn{3}{|c|}{}
\end{tabular}

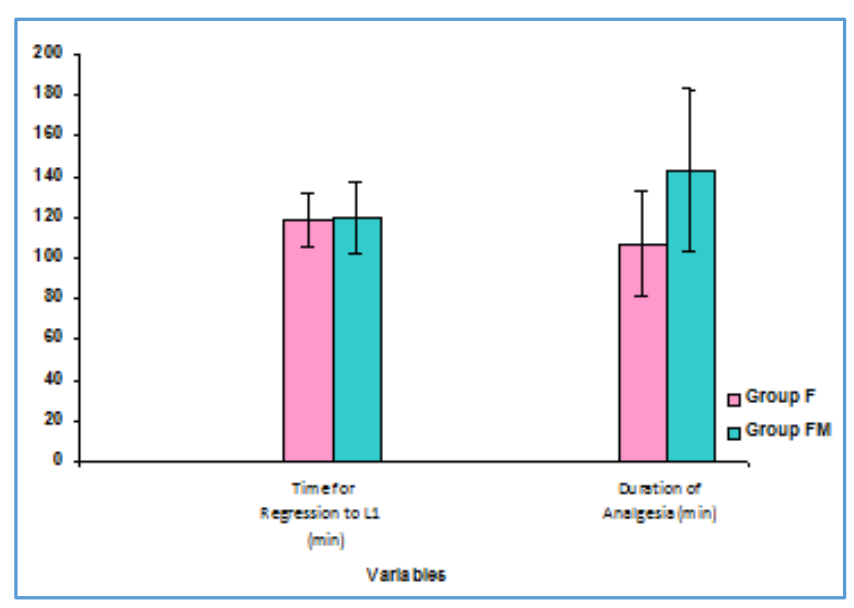

Fig. 1: Comparison of time to Regression to L1 and Duration of Analgesia in the two groups

Time taken for regression of sensory level to L1 was comparable in both the groups. Duration of analgesia (min) in Group FM was $143.40 \pm 39.57$ and in Group F was $107.00 \pm 25.82$ with a $\mathrm{p}<0.001^{* *}$. It was significantly prolonged in Group FM compared to Group F. Minimum analgesic duration in Group F was 65 min. and Group FM it was 80 min. Maximum analgesic duration in Group F was 170 min. and Group FM was 215 min.

\section{Pulse Rate in Two Groups}

\begin{tabular}{|c|c|c|c|}
\hline Pulse Rate & Group F & Group FM & Significance \\
\hline 1 minute & $84.16 \pm 13.45$ & $81.44 \pm 12.07$ & $\mathrm{~T}=0.753 ; \mathrm{p}=0.455$ \\
\hline 2 minutes & $84.16 \pm 14.25$ & $81.40 \pm 11.56$ & $\mathrm{~T}=0.752 ; \mathrm{p}=0.456$ \\
\hline 3 minutes & $83.84 \pm 13.99$ & $80.04 \pm 10.66$ & $\mathrm{~T}=1.080 ; \mathrm{p}=0.285$ \\
\hline 4 minutes & $84.76 \pm 14.12$ & $80.60 \pm 9.10$ & $\mathrm{~T}=1.238 ; \mathrm{p}=0.222$ \\
\hline 5 minutes & $84.64 \pm 14.16$ & $79.64 \pm 9.05$ & $\mathrm{t}=1.488 ; \mathrm{p}=0.143$ \\
\hline 10 minutes & $84.36 \pm 14.15$ & $79.48 \pm 8.19$ & $\mathrm{t}=1.493 ; \mathrm{p}=0.142$ \\
\hline
\end{tabular}

\begin{tabular}{|c|c|c|c|}
\hline 15 minutes & $84.16 \pm 13.31$ & $78.60 \pm 8.49$ & $\mathrm{t}=1.761 ; \mathrm{p}=0.085$ \\
\hline 20 minutes & $82.44 \pm 12.55$ & $79.60 \pm 8.89$ & $\mathrm{t}=0.924 ; \mathrm{p}=0.360$ \\
\hline 25 minutes & $83.00 \pm 12.43$ & $78.76 \pm 9.03$ & $\mathrm{t}=1.380 ; \mathrm{p}=0.174$ \\
\hline 30 minutes & $83.64 \pm 11.93$ & $79.20 \pm 8.66$ & $\mathrm{t}=1.506 ; \mathrm{p}=0.139$ \\
\hline 45 minutes & $82.96 \pm 10.02$ & $78.92 \pm 6.56$ & $\mathrm{t}=1.686 ; \mathrm{p}=0.098+$ \\
\hline 1 hr. & $84.84 \pm 9.41$ & $79.24 \pm 6.62$ & $\mathrm{t}=2.432 ; \mathrm{p}=0.019^{*}$ \\
\hline 1 hr $15 \mathrm{~min}$ & $85.17 \pm 10.10$ & $79.48 \pm 6.97$ & $\mathrm{t}=2.287 ; \mathrm{p}=0.027^{*}$ \\
\hline 1 hr $30 \mathrm{~min}$ & $87.95 \pm 9.75$ & $82.00 \pm 8.50$ & $\mathrm{t}=2.211 ; \mathrm{p}=0.032^{*}$ \\
\hline 1 hr $45 \mathrm{~min}$ & $89.46 \pm 8.92$ & $82.48 \pm 7.61$ & $\mathrm{t}=2.435 ; \mathrm{p}=0.021^{*}$ \\
\hline 2 hr. & $92.33 \pm 11.75$ & $85.88 \pm 6.77$ & $\mathrm{t}=1.693 ; \mathrm{p}=0.104$ \\
\hline 2 hr 30 min & $95.33 \pm 12.86$ & $86.10 \pm 6.99$ & $\mathrm{t}=1.675 ; \mathrm{p}=0.122$ \\
\hline Table 5: Comparison of Pulse rate (PR) between two groups \\
\hline
\end{tabular}

There was a significant increase in PR from the end of 1 hr. in Group F compared to Group FM.

Systolic BP in Two Groups

\begin{tabular}{|c|c|c|c|}
\hline $\begin{array}{c}\text { SBP } \\
(\mathrm{mm} \mathrm{Hg})\end{array}$ & Group F & Group FM & Significance \\
\hline 1 minute & $112.72 \pm 11.66$ & $113.6 \pm 8.89$ & $\mathrm{t}=0.300 ; \mathrm{p}=0.765$ \\
\hline 2 minutes & $111.80 \pm 12.03$ & $112.00 \pm 7.50$ & $\mathrm{t}=0.071 ; \mathrm{p}=0.944$ \\
\hline 3 minutes & $112.00 \pm 11.82$ & $112.64 \pm 8.21$ & $\mathrm{t}=0.222 ; \mathrm{p}=0.825$ \\
\hline 4 minutes & $111.40 \pm 12.49$ & $113.64 \pm 7.47$ & $\mathrm{t}=0.770 ; \mathrm{p}=0.445$ \\
\hline 5 minutes & $112.64 \pm 11.01$ & $113.40 \pm 8.16$ & $\mathrm{t}=0.277 ; \mathrm{p}=0.783$ \\
\hline 10 minutes & $112.88 \pm 10.8$ & $112.56 \pm 7.26$ & $\mathrm{t}=0.123 ; \mathrm{p}=0.903$ \\
\hline 15 minutes & $113.60 \pm 11.18$ & $112.92 \pm 7.93$ & $\mathrm{t}=0.248 ; \mathrm{p}=0.805$ \\
\hline 20 minutes & $113.72 \pm 11.48$ & $112.44 \pm 5.64$ & $\mathrm{t}=0.500 ; \mathrm{p}=0.619$ \\
\hline 25 minutes & $112.68 \pm 11.64$ & $113.56 \pm 5.86$ & $\mathrm{t}=0.338 ; \mathrm{p}=0.737$ \\
\hline 30 minutes & $112.08 \pm 10.34$ & $112.44 \pm 6.40$ & $\mathrm{t}=0.148 ; \mathrm{p}=0.883$ \\
\hline 45 minutes & $114.84 \pm 8.28$ & $114.36 \pm 5.33$ & $\mathrm{t}=0.142 ; \mathrm{p}=0.888$ \\
\hline $1 \mathrm{hr}$. & $116.60 \pm 9.79$ & $114.80 \pm 5.04$ & $\mathrm{t}=0.817 ; \mathrm{p}=0.418$ \\
\hline $1 \mathrm{hr} 15 \mathrm{~min}$ & $119.26 \pm 8.84$ & $115.36 \pm 4.91$ & $t=1.909 ; p=0.062+$ \\
\hline $1 \mathrm{hr} 30 \mathrm{~min}$ & $121.90 \pm 7.03$ & $117.62 \pm 5.43$ & $\mathrm{t}=2.301 ; \mathrm{p}=0.026^{*}$ \\
\hline $1 \mathrm{hr} 45 \mathrm{~min}$ & $126.15 \pm 10.14$ & $118.85 \pm 5.44$ & $\mathrm{t}=2.698 ; \mathrm{p}=0.011^{*}$ \\
\hline $2 \mathrm{hr}$. & $130.67 \pm 14.97$ & $119.74 \pm 6.19$ & $\mathrm{t}=2.638 ; \mathrm{p}=0.015^{*}$ \\
\hline $2 \mathrm{hr} 30 \mathrm{~min}$ & $124.67 \pm 5.03$ & $119.10 \pm 6.61$ & $\mathrm{t}=1.332 ; \mathrm{p}=0.210$ \\
\hline
\end{tabular}

There was significant increase in SBP from 1 hr. $30 \mathrm{~min}$ in Group F compared to Group FM.

\section{Oxygen Saturation Study}

\begin{tabular}{|c|c|c|c|}
\hline SPO2 (\%) & Group F & Group FM & Significance \\
\hline 1 minute & $98.88 \pm 0.78$ & $98.72 \pm 0.61$ & $\mathrm{Z}=0.797 ; \mathrm{p}=0.426$ \\
\hline 2 minutes & $98.80 \pm 0.76$ & $98.8 \pm 0.65$ & $\mathrm{Z}=0.269 ; \mathrm{p}=0.789$ \\
\hline 3 minutes & $98.96 \pm 0.73$ & $98.72 \pm 0.61$ & $\mathrm{Z}=1.435 ; \mathrm{p}=0.151$ \\
\hline 4 minutes & $98.88 \pm 0.78$ & $98.76 \pm 0.78$ & $\mathrm{Z}=0.464 ; \mathrm{p}=0.643$ \\
\hline 5 minutes & $98.76 \pm 0.83$ & $98.68 \pm 0.69$ & $\mathrm{Z}=0.274 ; \mathrm{p}=0.784$ \\
\hline 10 minutes & $98.72 \pm 0.74$ & $98.68 \pm 0.63$ & $\mathrm{Z}=0.121 ; \mathrm{p}=0.904$ \\
\hline 15 minutes & $98.96 \pm 0.68$ & $98.76 \pm 0.52$ & $\mathrm{Z}=1.081 ; \mathrm{p}=0.280$ \\
\hline 20 minutes & $99.00 \pm 0.65$ & $98.96 \pm 0.45$ & $\mathrm{Z}=0.241 ; \mathrm{p}=0.810$ \\
\hline 25 minutes & $98.92 \pm 0.76$ & $98.44 \pm 2.26$ & $\mathrm{Z}=0.425 ; \mathrm{p}=0571$ \\
\hline 30 minutes & $98.96 \pm 0.61$ & $98.80 \pm 0.58$ & $\mathrm{Z}=0.936 ; \mathrm{p}=0.349$ \\
\hline 45 minutes & $99.16 \pm 0.47$ & $99.00 \pm 0.41$ & $\mathrm{Z}=1.281 ; \mathrm{p}=0.200$ \\
\hline 1 hr. & $99.08 \pm 0.57$ & $98.96 \pm 0.45$ & $\mathrm{Z}=0.833 ; \mathrm{p}=0.405$ \\
\hline 1 hr 15 min & $99.13 \pm 0.55$ & $99.08 \pm 0.28$ & $\mathrm{Z}=0.502 ; \mathrm{p}=0.616$ \\
\hline 1 hr 30 min & $99.04 \pm 0.67$ & $98.95 \pm 0.46$ & $\mathrm{Z}=0.530 ; \mathrm{p}=0.596$ \\
\hline 1 hr 45 min & $99.15 \pm 0.38$ & $99.00 \pm 0.32$ & $\mathrm{Z}=1.236 ; \mathrm{p}=0.217$ \\
\hline 2 hr. & $99.17 \pm 0.41$ & $99.00 \pm 0.33$ & $\mathrm{Z}=1.015 ; \mathrm{p}=0.310$ \\
\hline 2 hr 30 min & $98.67 \pm 0.58$ & $99.00 \pm 0.00$ & $\mathrm{Z}=1.626 ; \mathrm{p}=0.068+$ \\
\hline \multicolumn{4}{|c|}{ Table 7: Comparison of Oxygen Saturation } \\
\hline \multicolumn{4}{|c}{}
\end{tabular}

There was no significant variation in oxygen saturation in both the groups after giving epidural drug and it was comparable in both the groups. 
Changes in Respiratory Rate

\begin{tabular}{|c|c|c|c|}
\hline RR & Group F & Group FM & Significance \\
\hline 1 minute & $16.92 \pm 2.66$ & $16.64 \pm 2.61$ & $\mathrm{~T}=0.376 ; \mathrm{p}=0.709$ \\
\hline 2 minutes & $17.20 \pm 2.74$ & $16.52 \pm 2.35$ & $\mathrm{~T}=0.943 ; \mathrm{p}=0.351$ \\
\hline 3 minutes & $17.16 \pm 2.72$ & $16.44 \pm 2.48$ & $\mathrm{~T}=0.978 ; \mathrm{p}=0.333$ \\
\hline 4 minutes & $17.32 \pm 2.94$ & $16.60 \pm 2.40$ & $\mathrm{~T}=0.949 ; \mathrm{p}=0.347$ \\
\hline 5 minutes & $16.76 \pm 2.52$ & $16.52 \pm 2.35$ & $\mathrm{~T}=0.348 ; \mathrm{p}=0.729$ \\
\hline 10 minutes & $17.12 \pm 2.59$ & $16.68 \pm 2.58$ & $\mathrm{~T}=0.602 ; \mathrm{p}=0.550$ \\
\hline 15 minutes & $16.88 \pm 2.47$ & $16.84 \pm 2.61$ & $\mathrm{~T}=0.056 ; \mathrm{p}=0.956$ \\
\hline 20 minutes & $16.80 \pm 2.16$ & $16.64 \pm 2.29$ & $\mathrm{~T}=0.254 ; \mathrm{p}=0.800$ \\
\hline 25 minutes & $17.12 \pm 2.26$ & $16.76 \pm 2.45$ & $\mathrm{~T}=0.539 ; \mathrm{p}=0.592$ \\
\hline 30 minutes & $17.44 \pm 2.62$ & $16.72 \pm 2.53$ & $\mathrm{~T}=0.990 ; \mathrm{p}=0.327$ \\
\hline 45 minutes & $17.64 \pm 2.48$ & $16.88 \pm 2.17$ & $\mathrm{~T}=1.154 ; \mathrm{p}=0.254$ \\
\hline 1 hr. & $17.40 \pm 2.47$ & $17.56 \pm 2.29$ & $\mathrm{~T}=0.238 ; \mathrm{p}=0.813$ \\
\hline 1 hr 15 min & $17.04 \pm 1.89$ & $17.28 \pm 1.90$ & $\mathrm{~T}=0.431 ; \mathrm{p}=0.669$ \\
\hline 1 hr 30 min & $17.71 \pm 2.39$ & $17.29 \pm 1.92$ & $\mathrm{~T}=0.657 ; \mathrm{p}=0.515$ \\
\hline 1 hr 45 min & $17.61 \pm 2.02$ & $17.30 \pm 2.18$ & $\mathrm{~T}=0.418 ; \mathrm{p}=0.679$ \\
\hline 2 hr. & $17.83 \pm 2.89$ & $17.78 \pm 2.09$ & $\mathrm{~T}=0.042 ; \mathrm{p}=0.967$ \\
\hline 2 hr 30 min & $17.33 \pm 2.08$ & $18.20 \pm 2.44$ & $\mathrm{~T}=0.553 ; \mathrm{p}=0.591$ \\
\hline \multicolumn{5}{|c|}{ Table 8: Comparison of Respiratory Rate } \\
\hline
\end{tabular}

There was no significant variation in respiratory rate, after giving epidural drug, in both the groups and they were comparable.

\section{Adverse Events}

\begin{tabular}{|c|c|c|c|}
\hline $\begin{array}{c}\text { Adverse } \\
\text { Events }\end{array}$ & $\begin{array}{c}\text { Group F } \\
(n=25)\end{array}$ & $\begin{array}{c}\text { Group FM } \\
(n=25)\end{array}$ & Significance \\
\hline Nausea/Vomiting & $1(4.0 \%)$ & $2(8.0 \%)$ & NS \\
\hline Pruritus & 0 & 0 & NS \\
\hline Urinary retention & 0 & $1(4.0 \%)$ & NS \\
\hline Others & 0 & 0 & NS \\
\hline
\end{tabular}

There was no significant difference in incidence of adverse effects like nausea/vomiting, pruritus, urinary retention and others in the two groups.

\section{DISCUSSION}

Postoperative pain may produce a range of detrimental effects and if not treated effectively may lead on to chronic postsurgical pain.12 Combined Spinal Epidural block is routinely used for infraumbilical surgeries including major orthopaedic and obstetric surgeries 4 as it takes care of postoperative pain. Effective single epidural dose for fentanyl is found to be 50-100 $\mu \mathrm{g} \mathrm{12,13}$ with rapid onset of analgesia in 5-10 min. and shorter duration of action (2-4 hr.). Bilir et al. ${ }^{9}$ used $50 \mathrm{mg}$ of bolus epidural magnesium followed by continuous epidural infusion of $100 \mathrm{mg}(24 \mathrm{~mL})$ for $24 \mathrm{hr}$. (1 $\mathrm{mL} / \mathrm{hr}$.) postoperatively, along with epidural fentanyl infusion for patient controlled epidural analgesia.

Arcioni et al. ${ }^{14}$ observed postoperative morphine consumption comparing intrathecal and epidural magnesium at different doses. Based on the above studies, we fixed the dose of epidural fentanyl $50 \mu \mathrm{g}$ bolus. We preferred to use a smaller dose of epidural magnesium bolus of $50 \mathrm{mg}$, that would not cause any side effects. In the present study, 50 patients posted for lower limb orthopaedic surgeries were studied to assess the effect of adding magnesium to fentanyl via epidural route for postoperative analgesia. Both groups were comparable with respect to age and sex. Highest level of sensory blockade achieved in both the groups was T6 and statistically similar between the groups $(\mathrm{p}=0.324)$.
Time taken for highest sensory level, duration of surgery and time taken for regression of sensory blockade to L1 were comparable in both the groups. There was significant prolongation of duration of analgesia in Group FM (143.40) compared to Group F (107.0) with $\mathrm{p}<0.001$. Out of 25 patients in Group F, maximum duration of analgesia was $170 \mathrm{~min}$. and minimum was $65 \mathrm{~min}$. with a Mean of 107.0 and SD of 25.82 . In Group FM, maximum duration of analgesia was $215 \mathrm{~min}$. and minimum was $80 \mathrm{~min}$. with a Mean of $143.4 \mathrm{~min}$. and SD of 39.57 .

Noxious stimulation leads to the release of neurotransmitters, which bind to various subclasses of excitatory amino acid receptors, including NMDA receptors. NMDA receptor signalling may be important in determining the duration of acute pain. ${ }^{15}$ Therefore, NMDA receptor antagonists may play a role in the prevention and treatment of post-injury pain. Mg blocks calcium influx and noncompetitively antagonises NMDA receptor channels. ${ }^{16} \mathrm{Mg}$ can have an effect on pain when used alone, but it has also been shown that it can reveal the analgesic properties of opioids. ${ }^{17}$ Therefore, co-administration of magnesium and fentanyl is expected to prolong fentanyl analgesia.

Bilir et al. ${ }^{9}$ used fentanyl PCEA in Group F and fentanyl PCEA with $50 \mathrm{mg}$ bolus $\mathrm{Mg}$ and continuous $\mathrm{Mg}$ infusion epidurally in Group FM, and found that time to first analgesic requirement (comparable to duration of analgesia in our study) was slightly longer in Group FM (51.6 min.) compared to Group F (37.1 min.). Patients in Group FM received smaller doses of epidural fentanyl at all-time points after $30 \mathrm{~min}$. compared to Group F. There was $25 \%$ reduction in fentanyl consumption in Group FM at the end of $24 \mathrm{hr}$. compared to Group F. This is similar to the present study wherein adding $\mathrm{Mg}(50 \mathrm{mg}$ ) to fentanyl (50 $\mathrm{gg}$ ) epidurally as a single dose markedly increased duration of fentanyl analgesia. R. Arcioni et al. ${ }^{14}$ used epidural $\mathrm{Mg}$ infusion and morphine for postoperative analgesia, though they have not recorded the time of first analgesic requirement, postoperative morphine requirements assessed for $36 \mathrm{hrs}$. were less in epidural magnesium group (24.0 $\mathrm{mg}$ ) compared to control group (38.96 mg). Mean morphine requirement was reduced by $38 \%$. Similar potentiation of fentanyl analgesia is seen with epidurally administered $\mathrm{Mg}$ as a single dose in our present study.

There was significant increase in PR in Group $F$ compared to Group FM from $1^{\text {st }}$ hour (Table 9, Fig. 18). Similarly, there was significant increase in SBP in Group F compared to Group FM from $1 \mathrm{hr}$. $15 \mathrm{~min}$. This could be attributed to patients' pain as it coincides with the Mean duration of analgesia in Group F is $107 \mathrm{~min}$, with minimum analgesic duration of $65 \mathrm{~min}$. and SD of 25.8. SPO2 and RR remained stable, and there was no significant difference between the groups. Thus, we infer that $\mathrm{Mg} 50 \mathrm{mg}$ given epidurally has no respiratory depressant effect and no adverse effects on haemodynamics. Bilir et al. ${ }^{9}$ and R. Arcioni et al. ${ }^{14}$ found that epidural $\mathrm{Mg}$ had no adverse effects on cardiorespiratory systems.

In these studies, the hemodynamic parameters were stable and comparable between the groups for the obvious reasons that one of the studies had used PCA and the other PCEA for postoperative analgesia. There was no statistically significant incidence of adverse events like nausea, vomiting, urinary retention, pruritus and others in both the groups. 
Neither there were differences in the incidence of these side effects between the groups in the above mentioned studies, nor were any additional adverse events.

The present study had certain limitations. Study group was very small. Preoperative serum Mg levels were not assessed in our patients which may affect pharmacodynamics of Mg. Motor blockade was not assessed, so no firm conclusions could be drawn about Mg induced changes in motor blockade. Since the distribution of the type of lower limb surgeries were uniform in both the groups (F and FM), the possibility of bias is minimised.

Thus, our clinical study confirms that epidurally administered Mg has a good safety profile in humans. And it is also shown to prolong the duration of fentanyl analgesia without any side effects.

\section{CONCLUSION}

In our study, comparing epidural fentanyl and epidural fentanyl plus magnesium for postoperative analgesia, the results were comparable with respect to highest sensory blockade attained, time taken for highest sensory blockade and time to regression of sensory blockade to L1. But duration of analgesia was significantly prolonged in Group FM compared to Group F. We found that co-administration of magnesium to epidural fentanyl for postoperative analgesia prolonged duration of fentanyl analgesia without any side effects.

\section{ACKNOWLEDGEMENT}

My special thanks to Dr. Suresh K.P. for helping me with the statistical analysis. I offer my sincere gratitude to all the faculty members of the Department of Anaesthesiology, VIMS, my colleagues, Dept. of Orthopaedics and the staff of the operating theatres, staff of PACU and staff of postoperative ward for their assistance and co-operation.

\section{REFERENCES}

1. Carr DB, Goudas LC. Acute pain. Lancet 1999;353(9169):2051-2058.

2. Joshi GP, Ogunnaike BO. Consequences of inadequate postoperative pain relief and chronic persistent postoperative pain. Anesthesiol Clin North Am 2005;23(1):21-36.

3. Barash Paul G, Cullen Bruce F, Stoelting Robert k, editors. Clinical anesthesia. Lippincott Williams \& Wilkins $2006 ; 6^{\text {th }}$ edn: 1475,1476 .
4. Rawal N, Holmström B, Crowhurst JA, et al. The combined spinal epidural technique. Anesthesiol Clin North Am 2000;18(2):267-95.

5. de Leon-Casasola OA, Lema MJ. Postoperative epidural opioid analgesia: what are the choices? Anesth Analg 1996;83(4):867-75.

6. Liu S, Carpenter RL, Neal JM. Epidural anesthesia and analgesia. Their role in postoperative outcome. Anesthesiology 1995;82(6):1474-1506.

7. Raj PP. Textbook of regional anaesthesia. Churchill Livingstone 2002;p. 505-24, 35-46.

8. Asokumar Buvanendran, Robert JM, Kroin S, et al. Intrathecal magnesium prolongs fentanyl analgesia: a prospective, randomized, controlled trail. $\mathrm{Br}$ J Anaesth 2007;98(4):519-23.

9. Bilir A, Gulec S, Erkan A, et al. Epidural magnesium reduces postoperative analgesic requirement. $\mathrm{Br} \mathrm{J}$ Anaesth 2007;98(4):519-23.

10. Bernard Rosner. Fundamentals of biostatistics. Duxbury 2000; $5^{\text {th }}$ edn:80-240.

11. Venkataswamy Reddy M. Statistics for mental health care research. NIMHANS publication India 2000;p.108144.

12. Ronald DM editor. Miller's anesthesia. Churchill Livingstone 2009; $7^{\text {th }}$ edn:p.2767,2758, 2760-7, 782-807, 1544, 1343, 2228.

13. Grass JA, Sakima NT, Schmidt R, et al. A randomized, double-blind, dose-response comparison of epidural fentanyl versus sufentanil analgesia after caesarean section. Anesth Analg 1997;85(2):365-71.

14. Arcioni R, Palmisani S, Tigano S, et al. Combined intrathecal and epidural magnesium sulfate supplementation of spinal anesthesia to reduce postoperative analgesic requirements: a prospective, randomized, double-blind, controlled trial in patients undergoing major orthopaedic surgery. Acta Anaesthesiol Scand 2007;51(4):482-9.

15. Wolf CJ, Thompson SW. The induction and maintenance of central sensitizations is dependent on N-methyl-Daspartic acid receptor activation: implications for the treatment of post-injury pain and hypersensitivity states. Pain 1991;44(3):293-9.

16. Fawcett WJ, Haxby EJ, Male DA. Magnesium; physiology and pharmacology. Br J Anaesth 1999;83(2):302-20.

17. Begon S, Pickering G, Eschalier A, et al. Magnesium increases morphine analgesic effect in different experimental models of pain. Anesthesiology 2002;96(3):627-32. 